ECOLOGICA, Vol. 28, No 102 (2021), 193-200

https://doi.org/10.18485/ecologica.2021.28.102.8

Originalni naučni rad

UDC: $65.012 .32: 614.2]:[616.98: 578.834]$

\title{
Krizni menadžment zdravstvenih sistema u uslovima pandemije COVID-19
}

\section{Crisis management of healthcare systems in the conditions of the COVID-19 pandemic}

\author{
Sanja Dobričanin ${ }^{1 *}$, Ljiljana Arsić2 $^{2}$ Vladimir Dobričanin ${ }^{3}$, Anđelka Tripković4 \\ 1,2,4Univerzitet u Prištini sa privremenim sedištem u Kosovskoj Mitrovici, Ekonomski fakultet, Kolašinska \\ 156, 38220 Kosovska Mitrovica / University of Priština (temporary in Kosovska Mitrovica), Faculty of \\ Economics, Kolašinska 156, 38220 Kosovska Mitrovica \\ ${ }^{3}$ Klinički centar Crne Gore, Džona Džeksona bb., 81000 Podgorica, Crna Gora / \\ Clinical Centar of Montenegro, Džona Džeksona bb., 81000 Podgorica, Montenegro \\ *Autor za prepisku / Corresponding author
}

Rad primljen / Received: 18.12.2020, Rad prihvaćen / Accepted: 10.05.2021.

\begin{abstract}
Sažetak: „Moderna“ kriza izazvana pandemijom COVID-19 ostavila je i ostavlja nesagledive posledice na globalnom nivou. Opšte poznata činjenica je da je ova pandemija pored velike zdravstvene, pokrenula i izazvala najozbiljniju ekonomsku krizu od Drugog svetskog rata, krizu skoro pet puta razorniju od one iz 2008. godine. Prvi na udaru pandemije korona virusa bili su zdravstveni sistemi. Razlog tome je značajan broj zaraženih i bolesnih kojima je neophodna zdravstvena pomoć i nega. U uslovima organizacionog haosa, u stresnim okolnostima koju karakteriše nedostatak preciznih informacija, krizni menadžment postaje važan faktor odgovornog upravljanja zdravstvenim sistemima. Krizni menadžment je naziv za sve vrste aktivnosti usmerene na postupanje sa sistemom u stanju vanrednih situacija: prevenciju, ublažavanje (mitigacija), reagovanje i oporavak. Efikasan krizni menadžment podrazumeva spremnost za odgovor na ovakve krizne situacije. Procenjivanje i prepoznavanje kapaciteta je od krucijalnog značaja za krizni menadžment imajući u vidu da upravo kapaciteti određuju spremnost privrede da se izbori sa kriznim situacijama.
\end{abstract}

Ključne reči: krizni menadžment, kriza, COVID-19, zdravstveni sistem.

\begin{abstract}
The "modern" crisis caused by the COVID-19 pandemic has left and leaves unforeseeable consequences on a global level. It is a well-known fact that this pandemic, in addition to the greatest health impact, initiated and caused the most serious economic crisis since the Second World War, a crisis almost five times more destructive than the one from 2008. The first to be hit by the COVID-19 pandemic were health systems. The reason for that is a significant number of infected people who were in need for medical care. In conditions of organizational chaos, in stressful circumstances characterized by a lack of accurate information, crisis management becomes an important factor of the responsible health care management. Crisis management is the name for all types of activities aimed at dealing with the system in a state of emergency: prevention, mitigation, response and recovery. Effective crisis management implies readiness to respond to such crisis situations. Assessing and recognizing existing capacities is essential for crisis management because total capacities determine the readiness of a system in crisis for an adequate response.
\end{abstract}

Keywords: crisis management, crisis, COVID-19, health system.

${ }^{1}$ orcid.org/0000-0003-1804-9374, e-mail: sanja.dobricanin@pr.ac.rs

2orcid.org/0000-0002-3582-8161, e-mail: ljiljana.arsic@pr.ac.rs

${ }^{3}$ orcid.org/0000-0003-0342-9000, e-mail: vladimir.dobricanin@icloud.com

4orcid.org/0000-0002-3972-4933, e-mail: andjelka.tripkovic@pr.ac.rs 


\section{UVOD / INTRODUCTION}

Moderno doba oličeno u intezivnim i brzim promenama u okruženju, rapidnom razvoju tehnologije i tehnike, erupciji ljudskog znanja, pogodan je ambijent za nastajanje i razvoj mnogobrojnih kriza različitog porekla. Ekonomska nestabilnost, politička previranja, klimatske promene izazvane globalnim otopljavanjem, razne pandemije (AIDS, SARS, H1N1, Ebola, danas korona virus) su samo od nekih razloga koji dovode do ozbiljnih kriza kako na nacionalnom tako i na svetskom nivou. Poslednja dešavanja prouzrokovana pandemijom virusa COVID-19, ponovo su ukazala na značaj kriznog menadžmenta, nedostatake i prednosti njegove primene u novonastaloj situaciji.

Ozbiljniji razvoj kriznog menadžmenta kao naučne discipline vezuje se za rešavanje krize izazvane trovanjem pacijenata lekom Tylenol (najpoznatiji analgetik u SAD) firme Johnson\&Johnson 1982. godine. Ovaj slučaj je postao model za efikasno upravljanje korporativnim krizama i ujedno napravio prekretnicu i postavio standarde u oblasti kriznog menadžmenta. Međutim, poreklo ovog termina vezuje se za političku sferu i Kubansku raketnu krizu 1962. godine. Tadašnji predsednik SAD-a Dž. F. Kenedi, kriznim menadžmentom je definisao upravljanje jednom veoma delikatnom, vanrednom situacijom koja je mogla da dovede do izbijanja Trećeg svetskog rata (Kešetović i dr., 2012).

Kad se govori o kriznom menadžmentu, potrebno je naglasiti da on pre svega predstavlja određenu vrstu primenjenog menadžmenta koji prema Điljotiju i Ronaldu predstavlja sposobnost organizacije da postupa brzo, efikasno i efektivno u mogućim operacijama koje imaju za cilj smanjivanje pretnji ljudskom zdravlju i bezbednosti, umanjenje štete na javnoj ili korporacijskoj imovini i smanjenje negativnog uticaja na nastavak normalnog poslovanja ili drugih operacija (Milašinović i dr., 2009).

Krizni menadžment može se definisati kao skup funkcija koji imaju za cilj da identifikuju, izuče i predvide moguće krizne situacije i uspostave posebne načine koje će organizaciji omogućiti sa spreči krizu ili da se sa njom izbori i da je prevaziđe, uz minimiziranje posledica njenog dejstva i što brži povratak u normalno stanje. Krizni menadžment je naziv za sve vrste aktivnosti usmerene na postupanje sa sistemom u stanju vanrednih situacija: prevenciju, ublažavanje (mitigacija), reagovanje i oporavak. Prema tome, osnovni zadaci kriznog menadžmenta su identifikovanje, izučavanje i predviđanje mogućih kriznih događaja, i na osnovu toga kreiranje modela koji će omogućiti pravovremenu reakciju i prevazilaženje krizne situacije u cilju što bržeg povratka u normalno stanje.
Cilj rada je da ukaže na značaj kriznog upravljanja zdravstvenim sistemima i ustanovama u uslovima pandemije izazvane infekcijom virusom SARS-CoV-2 na primeru Crne Gore. Novonastala situacija je samo afirmisala značaj kriznog menadžmenta i dala mu centralnu ulogu u procesu rešavanja krize. $U$ prilog tome govori činjenica da ovaj segment menadžmenta prati veliki broj naučnih članaka, publikacija, konferencija koji su posvećene upravljanju kriznim situacijama u uslovima pandemije. Istovremeno, u okviru kompanija, u profitnom i neprofitnom sektoru, u državnim institucijama se angažuju pojedinci i osnivaju timovi čiji je osnovni zadatak pronalaženje rešenja usmerenih ka rešavanju ove vanredne situacije.

\section{PANDEMIJA I NJEN POČETAK U CRNOJ GORI I PANDEMIC AND IT'S ONSET IN MONTENEGRO}

Dana 30. januara 2020. godine, generalni direktor Svetske zdravstvene organizacije (SZO) proglasio je izbijanje bolesti izazvane koronavirusom (COVID19) javnom vanrednom situacijom od međunarodne važnosti prema Međunarodnim zdravstvenim propisima (IHR 2005). Pandemija je proglašena 11. marta 2020. godine i zahvatila je 180 od 193 zemalja članica Ujedinjenih nacija (Radanov, 2020).

Kao odgovor na pandemiju COVID-19, SZO sprovodi svoj Strateški plan spremnosti i odgovora (SPRP), u kome je svaka nacionalna vlada pozvana da detaljno objavi svoj Plan spremnosti i odgovora u svojoj zemlji (PRP) u skladu sa osam vodećih principa. Nažalost, Crna Gora niti je imala, niti je pripremila navedeni plan, tako da je svaki odgovor do sada bio sporadičan, nesistematičan, često neodgovarajući u odnosu na epidemiološku situaciju što je prouzrokovalo donošenje i primenjivanje mera koje su bile preoštre i koje su dovele do ekonomske degradacije Crne Gore, što je pretilo potpunim ekonomskim kolapsom. Ovakav pristup bio je i uzrok naglog gubitka nekoliko hiljada radnih mesta, a ekonomska dobit od turizma smanjena je za gotovo $90 \%$.

Nakon avgustovskih nacionalnih izbora i formiranja nove političke i parlamentarne većine dolazi do smanjenja aktivnosti svih tela koja su u prethodnom periodu bila zadužena za praćenje i kontrolu pandemije. U periodu do 2. decembra kada nova Vlada preuzima de facto i vlast, navedena tela su malo pažnje i aktivnosti usmeravale ka rešavanju krizne situacije, što je rezultiralo nažalost sve većim brojem obolelih. Početak 2021. godine karakteriše nastavak trenda povećanja broja inficiranih koji je dominantan u mlađoj populaciji. Nova Vlada preduzima određene korake u odnosu na epidemiološku situaciju, a pristižu i prvi kontingenti vakcina ruskog i kineskog proizvođača. U martu mesecu započet je proces vakcinacije protiv SARS-CoV-2 virusa po preporučenim šemama. 


\section{MATERIJALI I METODE /} MATERIALS AND METHODS

Crnogorski zdravstveni sistem je, po većini parametara, relativno mali sistem i kao takav pogodan je za uvođenje i primenu novih znanja i iskustava, te relativno brzu transformaciju u jedan moderan, kvalitetan i efikasan sistem koji je sposoban da u potpunosti zadovolji potrebe krajnjih korisnika svojih usluga.

Zdravstveni sistem Crne Gore je organizovan kao jedinstveni zdravstveni region i dominantno se zasniva na javnom sektoru. Javne zdravstvene ustanove su organizovane kroz mrežu primarne, sekundarne i tercijarne zdravstvene zaštite, koja se sastoji od 18 domova zdravlja, sedam opštih bolnica, tri specijalne bolnice, Kliničkog centra Crne Gore, Zavod za transfuziju krvi, Zavoda za hitnu medicinsku pomoć, Instituta za javno zdravlje i Apotekarske ustanove Crne Gore, „Montefarm" u čijem sastavu se nalazi 41 apoteka u svim opštinama Crne Gore. Privatni sektor koji trenutno nije u potpunosti integrisan u sistem zdravstvene zaštite, sastoji se od većeg broja ordinacija, pre svega stomatoloških ordinacija, veledrogerija, apoteka kao i dve specijalne bolnice.

U zdravstvenom sistemu Crne Gore radi oko 2.000 doktora. Oko 1.600 radi u javnim zdravstvenim ustanovama, dok ostatak radi u privatnom sektoru. Zdravstveni budžet za 2020. godinu iznosio je 281.5 miliona evra. I pre početka pandemije ZS Crne Gore se suočavao sa ozbiljnim problemima kao što su neadekvatni modeli finansiranja, nedovoljno ulaganje u primarnu zdravstvenu zaštitu, prevenciju i javno zdravlje, nedostatak zdravstvenih radnika, rashodi za zdravlje koji su niži od EU proseka. Opšti kvalitet sistema zdravstvene zaštite meri se i spremnošću da odgovori na događaje sa masovnim žrtvama, vanredne situacije i katastrofe (Dobričanin i dr., 2018). Međutim, prisustvo pandemije je samo dodatno potvrdilo izuzetnu osetljivost $\mathrm{i}$ ranjivost ovog zdravstvenog sistema.

Prema Indeksu GHSI (Global Health Security Index) otpornost zdravstvenog sistema i njegov kapacitet za lečenje obolelih i zaštitu zdravstvenih radnika prepoznati su kao slabe tačke u zdravstvu Crne Gore. Crna Gora je dobila najniže ocene za kapacitet zdravstvenog sistema u okviru koga se razmatraju činioci poput: zdravstvenog kapaciteta u kliničkim centrima, bolnicama i domovima zdravlja; medicinskih protivmera i upućivanja zaposlenih na zadatke; pristupa zdravstvenoj zaštiti; komunikacije sa zdravstvenim radnicima u slučaju vanredne javno-zdravstvene situacije; prakse kontrole zaraze i dostupnosti opreme. Indeksom GHSI se mere aspekti sprečavanja, otkrivanja, brzog odgovora, poš- tovanja međunarodnih standarda, okruženja rizika i kapaciteta zdravstvenog sistema.

$\mathrm{U}$ toku istraživanja zdravstvenog sistema Crne Gore korišćene su induktivno-deduktivne metode i metode analize i sinteze, uz paralelno istraživanje i proučavanje inostranih iskustava u primeni kriznog menadžmenta u uslovima pandemije. Za potrebe istraživanja korišćeni su podaci dostupni na sajtu Instituta za javno zdravlje Crne Gore.

\section{KRIZNI MENADŽMENT U DOBA KORONE / CRISIS MANAGEMENT IN THE COVID-19 ERA}

Nespremnost država i sistema da odgovore na vanredne događaje dovele su, ne samo do smanjenja efikasnosti odgovora na prevenciju i mitigaciju posledica pandemije, već i do ispoljavanja svih elemenata vanredne situacije izazvane pandemijom:

- vremenski pritisak na donosioce odluka od prvih simptoma pojave virusa nepoznatog porekla;

- rapidna eskalacija epidemije i progresivno ograničavanje povoljnosti za reagovanje;

- pretnja po fundamentalne vrednosti - zdravlje građana/zaposlenih, ugled, imovinu, ekonomiju;

- nedovoljnost/neadekvatnost resursa, pre svega lekarskog osoblja, medicinskih i zaštitnih sredstava i opreme, kao i drugih zdravstvenih kapaciteta;

- nesigurnost menadžmenta na raznim nivoima, zaposlenih, lanaca snabdevanja, drastična ograničenja kretanja ljudi, roba i usluga;

- informacioni deficit/suficit: nedostatak ključnih i pouzdanih informacija o poreklu virusa, načinima prenošenja, kliničkoj slici, kao i ograničenja u procesuiranju kontradiktornih informacija koje imaju za posledicu ekstremno loše strukturiran proces odlučivanja;

- postojeći planovi su pre izvor problema nego rešenja zbog brojnosti faktora koji utiču na razvoj situacije i njihove kontinuirane promene;

- globalni karakter i prekogranični efekti događaja, a posebno njegovo trajanje uz trend da postaje sezonska bolest, obesmišljavaju svaku postojeću karakterizaciju događaja po njihovoj učestalosti. Umesto o pojedinačnim događajima, pre možemo govoriti o pojavi, u najmanju ruku produženog dejstva, koja sa manjim ili većim stepenom intenziteta pokazuje izuzetne migratorne sposobnosti, menjajući svoju fizionomiju i načine ispoljavanja; 
- $\quad$ posledice događaja su sve kompleksnije i nepredvidljivije zbog domino efekata koji ima na sve sfere ljudske delatnosti;

- evidentno je zgušnjavanje događaja s trendom povećanja razornosti njihovih efekata. Imajući u vidu hronologiju i kontinuitet epidemija u 21. veku, očigledno je da su periodi između njihovih dešavanja sve kraći, mogućnosti za pripravnost i reagovanje sve više ograničene, i sve teži su zahtevi koji se postavljaju pred menadžerske strukture (Keković, 2020).

Kvalitet jednog zdravstvenog sistema, između ostalog, se procenjuje i po njegovoj spremnosti za odgovor na vanredne situacije i katastrofe. Nespremnost, ili samo delimična spremnost, može dovesti do nesagledivih posledica po ukupno zdravlje stanovništva što dalje ugrožava sve segmente društvenog sistema. Upravo je jedna ovakva kriza dovela do demistifikacije „najboljih“ zdravstvenih sistema jer je italijanski zdravstveni sistem bio smatran kao jedan od najefikasnijih, dok je odgovor na COVD-19 krizu bio u najmanju ruku patetičan i haotičan. Takav neefikasan pristup, bez efikasnog kriznog menadžmenta, doveo je do gubitka velikog broja života i kolapsa zdravstvenog sistema koji nije viđen ni u jednoj drugoj zemlji. Razlog ovakvog kolapsa je neprepoznavanje hazarda i potpuni promašaj u proceni i kontroli rizika, te potpuno nepostojanje mera prevencije i organizovanje dva događaja koja su dovela do eksplozije takozvane epidemiološke bombe: Milano Fashion Week-a i fudbalske utakmice lige šampiona između Atalante i Valensije. lako je SZO upozorila na postojanje javnozdravstvene vanredne situacije od međunarodnog značaja $\mathrm{s}$ velikim potencijalom za proglašenje pandemije, zdravstvene i političke vlasti Italije nisu na vreme anticipirale upozorenja što je kasnije plaćeno nezapamćenom stopom smrtnosti koja je bila jedinstvena u Evropi.

Posle Italije, Španije, Francuske, pa i Velike Britanije, postalo je jasno koliko su zdravstveni sistemi bivših socijalističkih država, koji su bili okrenuti čoveku, vitalniji od kapitalističkih baziranih na visokim i skupim tehnologijama. To je bilo najuočljivije na primeru Nemačke, gde je odgovor na krizu bio neuporedivo efikasniji u njenom istočnom delu (Ristanović, 2020).

Conditio sine qua non za odgovarajuće funkcionisanje kriznog menadžmenta je postojanje plana za upravljanje kriznim, odnosno, vanrednim situacijama. Ovaj plan mora biti zasnovan na savremenim principima upravljanja kriznim situacijama koji podrazumevaju sledeće elemente: određivanje prioriteta; identifikaciju hazarda; procenu rizika; prevenciju; mitigaciju; brzo reagovanje; opravak; unapređenje budućih odgovora kroz naučene lekcije.

Upravo je i cilj plana kriznog menadžmenta sledeći:

- zaštititi živote, imovinu i životnu sredinu;

- ublažiti posledice prouzrokovane vanrednim situacijama kao i obezbeđivanje kontinuteta opštih usluga;

- $\quad$ kreirati sistem i mrežu za reagovanje ali i oporavak od posledica vanredne situacije;

- optimalno korišćenje raspoloživih resursa;

- obezbeđivanje dodatnih resursa ukoliko se ukaže potreba;

- poboljšanje interagencijeske i intersektorske saradnje unutar države i saradnje $s$ međunarodnim agencijama (World Health Organization, 2009).

Prvi i osnovni cilj plana je formiranje nacionalnog koordinacionog tela koje će upravljati krizom na najvišem nacionalnom, političkom i stručnom nivou. Ovo telo je locirano u Vladi i njime predsedava premijer u parlamentarnim ili predsednik u predsedničkim političkim sistemima. Nije preporučljivo da ovim telom predsedava neko ko je od strane premijera ili predsednika imenovan jer se na taj način umanjuje značaj same krize i ujedno smanjuje efikasnost samog tela. U Crnoj Gori je u periodu od marta 2020. do decembra 2021. godine rukovodilac ovog tela bio ministar poljoprivrede, a nakon formiranja nove Vlade, ovim telom je koordinisala ministarka zdravlja. Nakon usvajanja plana za odgovor na pandemiju COVID-19, na čelo ovog tela dolazi premijer Crne Gore. Na ovaj način se dokazuje puna posvećenost donosilaca odluka rešavanju jedne od najvećih pretnji XXI veka.

Donošenje ovakvih planova mora biti usaglašeno s nacionalnim i mađunarodnim zakonodavstvom kao i usklađeno s preporukama međunarodnih agencija koja se bave menadžmentom kriznih situacija. Jedna od najznačajnijih agencija je i SZO koja je još marta meseca prošle godine donela preporuke za izradu strateškog plana za spremnost i reagovanje (WHO - COVID-19 Strategic Preparedness and Response Plan). Krizni plan upravljanja COVID19 krizom se sastoji od nekoliko ključnih elemenata:

\section{Koordinacija, planiranje i monitoring}

Formiranje tela za koordinaciju i kontrolu na nivou Vlade u svom sastavu mora uključiti sva relevantna ministarstva koja su ključna u upravljanju ovakvom kriznom situacijom. $U$ ovoj fazi se aktivira multisektorska i interagencijska saradnja kako bi se unapredili njihovi koordinacioni mehanizmi. Jedan od prvih zadataka je i izrada plana za spremnost u reagovanje na pandemiju COVID-19. Za izradu 
ovog plana formira se tim kompetentnih profesionalaca koji će kreirati plan, jasnog i konkretnog za sve predviđene učesnike, ne samo one koji upravljaju krizom već i za one koji će svojim postupcime neposredno uticati na ostvarenje tog plana. Jedan od ključnih koraka je i izrada inicijalne procene ukupnih kapaciteta, analize rizika uključujući i identifikaciju i mapiranje vulnerabilnih grupa. Procena ukupnih kapaciteta određuje spremnost na odgovor na krizu. Identifikacija i mapiranje vulnerabilnih grupa ključno je za kontrolu pandemije i smanjenje smrtnosti. Uspostavljanje sistema evaluacije efektivnosti primenjenih mera je komponeneta koju ovo telo prati i na osnovu merljivih indikatora rukovodi pooštravanjem odnosno popuštanjem preventivnih mera i mera mitigacije. Ovo je jedan od elemenata koji je bio najkritikovaniji od strane građana jer je često bio nesrazmeran i dovodio je do ozbiljnih ekonomskih problema kao i problema u poštovanju ljudskih prava.

\section{Krizna komunikacija i PR}

Komunikacija u doba pandemije predstavlja jednu od okosnica uspeha primene svih preventivnih i mitigacionih mera. Ona je ključ uspeha prihvatanja istih od strane zajednice kao i postizanje povjerenja u nadležne donosioce odluka. Predstavljanje informacija o tome šta se zna o COVID-19 pandemiji, a šta se ne zna, šta je urađeno i šta se planira da se dalje uradi, ključne su informacije koje stanovništvu treba redovno predstavljati kako bi se izbegle nejasnoće i nepoverenje kao i sprečilo širenje dezinformacija i panike. Empatično, transparentno i dosledno slanje poruka preko pouzdanih medija, preko ključnih i uticajnih pojedinaca ima suštinski karakter uspostavljanja autoriteta i poverenja. Ključna je identifikacija osoba koje će biti zadužene za PR i komunikaciju sa građanima i javnošću uopšte. Te osobe moraju biti stručne uz posedovanje oratorskih kvaliteta kako bi jasno prenele potrebne poruke i kako bi one bile jasne građanima kojima su namenjene. Svaka izjava i svako plasiranje određenih informacija mora proći odgovoarajuću proveru verodostojnosi podataka i pouzdanosti izvora kako bi se izbegle nejasnoće i na taj način gubilo preko potrebno poverenje. Identifikovanje pojedinaca i grupa koje uživaju poverenje građana može biti ključno u procesu plasiranja poruka. Ti pojedinci se mogu potražiti među liderima, javnim ličnostima, glumcima, pevačima, kod nas naročito među crkvenim velikodostojnicima i verskim vođama, internet influenserima koji imaju veliki uticaj na mlađu populaciju itd. Ovi pojedinci mogu odigrati ključnu ulogu u situacijama koje mogu biti presudne u implementaciji svih tačaka plana.

\section{Tačke ulaska (granični prelazi)}

Kontrola graničnih prelaza je ključna za prevenciju i kontrolu importacije COVID-19 infekcije. Ključna uloga brzog testiranja dolazi do izražaja na ovim tačkama jer se jedino masovnim testiranjem ili traženjem dokaza o trenutnom nepostojanju COVID19 infekcije kod domaćih građana i stranaca može garantovati odgovarajuće sprovođenje preventivnih mera kojima se može efikasno kontrolisati importacija infekcije.

\section{Testiranje}

Masovno testiranje se pokazalo kao jedno od glavnih oružja za borbu protiv COVID-19 infekcije. Kroz masovna testiranja dobija se jasan uvid u realno stanje distribucije infekcije među stanovništvom na osnovu čega se mogu primeniti odgovarajuće mere na lokalnom ili nacionalnom nivou. Testiranje osoba na tačkama ulaska, odnosno na graničnim prelazima, doprinosi smanjenju mogućnosti importacije novih slučajeva koji mogu značajno da doprinesu kasnijem lokalnom širenju infekcije COVID-19.

\section{Bolnički kapaciteti}

Monitoring nad bolničkim kapacitetima vrše Ministarstvo zdravlja i Institut za javno zdravlje. Praćenje popunjenost kapaciteta COVID kreveta je ključno radi pravovremene intervencije u smislu povećanja broja kreveta u određenim COVID bolnicama. Pored navedenog, ključno je i praćenje angažovanosti ljudskih resursa kako bi se izbegao overburn sindrom najangažovanijeg osoblja. Pravilnim rasporedom opterećenja zdravstvenih radnika i zdravstvenih saradnika izbegava se preopterećenje pojedinaca u COVID odeljenjima. Preraspodela ključnog stručnog kadra je u nadležnosti Ministarstva zdravlja. Relociranjem ključnih specijalista iz specijalizovanih bolnica može se poboljšati kvalitet pružanja zdravstvene usluge obolelima od COVID19 infekcije. Posebnu pažnju treba posvetiti angažovanju psihologa i socijalnih radnika kako bi se pružila psihosocijalna podrška pacijentima obolelim od COVID-19 infekcije. Značajnu pažnju treba posvetiti uspostavljanju kontinuiteta pružanja zdravstvenih usluga stanovništvu kao i nastavak svih skrining programa kako bi se izbegli prekidi u pružanju odgovarajuće zdravstvene zaštite.

\section{Podrška, logistika i intersektorska saradnja}

Mapiranje dostupnih i rezervnih resursa ključno je radi postizanja kontinuiteta pružanja podrške borbi protiv COVID-19 pandemije. U ovakvim kriznim situacijama koje su pandemijskog karaktera i kada je celokupna civilizacija u stanju recesije mora se obezbediti sigurno snabdevanje osnovnim proizvodima, lekovima i medicinskim sredstvima koji su 
neophodni za funkcionisanje ne samo zdravstvenog sistema već i drugih, za građane vitalnih službi.

\section{Vakcinacija}

Sprovođenje efikasnog sistema vakcinacije je u nadležnosti Ministarstva zdravlja, Instituta za javno zdravlje, opštih i specijalnih bolnica i Domova zdravlja. Efikasnost procesa vakcinacije mora biti zasnovana na merljivim indikatorima koje će odrediti nadležni u Institutu. Informacije o samom procesu vakcinacije dostavljaju se Vladinom telu preko Ministarstva zdravlja. Jedan od najbitnijih zadataka za uspešnost vakcinacije jeste edukacija građana o njenom značaju. Međutim, snaga takozvanih antivaksera je izuzetna, te je u pojedinim zemljema i u pojedinim zajednicama odziv na vakcinaciju nedopustivo nizak te se na taj način kompromituje uspeh kompletnog plana.

\section{Izveštavanje i razmena informacija}

Redovno izveštavanje donosilaca odluka je ključno za pravovremeno intervenisanje u merama implementacije kada je to neophodno. Izveštavanje mora biti dovoljno jasno i uniformno kako bi svi merljivi indikatori mogli biti identifikovani na odgovarajući način. Dodatne informacije koje su bitne za koordinaciju od strane Vladinog koordinacionog tela mogu se plasirati ad hoc. Komunikacija sa međunarodnim faktorima i agencijama je ključna i ona se odvija po već predodređenoj dinamici. Razmena informacija dvosmernog tipa je neophodna kako bi se nacionalni i internacionalni faktori mogli prilagoditi novonastalim situacijama koje mogu biti od ključnog značaja za uspeh u primeni plana za spremnost i reagovanje na COVID-19 pandemiju.
Postojanje adekvatnog kriznog plana je prioritet u uslovima postojanja vanrednih situacija. Ono što se treba naglasiti da je svaka kriza jedinstven i neponovljiv događaj što zahteva kreiranje fleksibilnih kriznih planova koji će se uz neznatne korekcije moći prilagoditi trenutnoj situaciji. Implementacija svih aspekata kriznog menadžmenta nikad ne može u potpunosti pripremiti državu na adekvatnu reakciju, što je i pandemija virusa COVID-19 i pokazala, ali može uspostaviti fleksibilne i prilagodljive mehanizme koji u mnogome mogu smanjiti posledice ovakvih situacija i kupiti potrebno vreme kako bi se pronašli pravilni modaliteti reagovanja (Marković i dr., 2020).

\section{REZULTATI I DISKUSIJA / RESULTS AND DISCUSSION}

Spremnost kriznog menadžmenta u vanrednim situacijama kakva je pandemija SARS-COV-2 virusa došla je do izražaja u svim zemljama sveta, počevši od onih najrazvijenijih pa sve do takozvanih zemalja "trećeg sveta“. lako su ove prve neuporedivo bogatije $\mathrm{i}$, na neki način uređenije, u situaciji pandemije se nisu pokazale spremnim za dogovor o zajedničkom delovanju. Decenijama unazad, Svetska zdravstvena organizacija (SZO) pokušava raznoraznim dogovorima i ugovorima da natera savremene demokratije da se posvete organizaciji kriznog menadžmenta na bazi pristupa svim hazardima (All Hazard Approach), i na taj način podignu svest i spremnost za odgovor na ovakve vanredne situacije i katastrofe. Statističko-epidemiološka situacija u Crnoj Gori na dan 18. marta 2021. godine, tačno godinu dana od prvog slučaja SARS-CoV-2 infekcije, prikazana je u Tabeli 1.

Tabela 1 - Broj inficiranih, izlečenih i umrlih od SARS-CoV-2 infekcije

Table 1 - Number of infected, cured and died of SARS-CoV-2 infection

\begin{tabular}{|l|c|c|c|}
\hline & Svet & Region & Crna Gora \\
\hline Ukupno slučajeva & 117.202 .064 & 4.678 .685 & 85.253 \\
\hline Izlečeni & 93.943 .674 & 4.244 .977 & 75.503 \\
\hline Umrli & 2.652 .282 & 68.660 & 1.169 \\
\hline
\end{tabular}

Izvor: Autori / Source: Authors

Pik pandemije $u$ poslednjih 8 meseci bio je $u$ novembru kada je ukupan broj aktivnih slučajeva bio preko 11.000 (Grafikon 1). Većina obolelih (78,33\%) pripada mlađoj populaciji, dok $21,67 \%$ pripada starijoj populaciji gde je stopa smrtnosti značajnije veća i u proseku iznosi oko 15\%. Procenat hospitalizovanih je opadao kako se kvantum znanja o COVID-u uvećavao, tako da je u avgustu mesecu iznosio oko $13 \%$ od broja obolelih, dok se u decembru kretao oko 4\%. Ovaj pad hospitalizacija uzro- kovan je i povećanjem svesti građana, naročito starije populacije o putevima širenja virusa pa je većina obolelih pripadala mlađim dobnim grupama gde je smrtnost značajno niža, oko $0,4 \%$ (Grafikon 2). Pored toga, ovakav pozitivan trend, koji se i dalje nastavlja, je dokaz da država i celokupni zdravstveni sistem, bez obzira na trenutnu nespremnost, uspevaju da kroz primenu osnovnih postulata kriznog menadžmenta dobijaju bitku u ovoj borbi. 


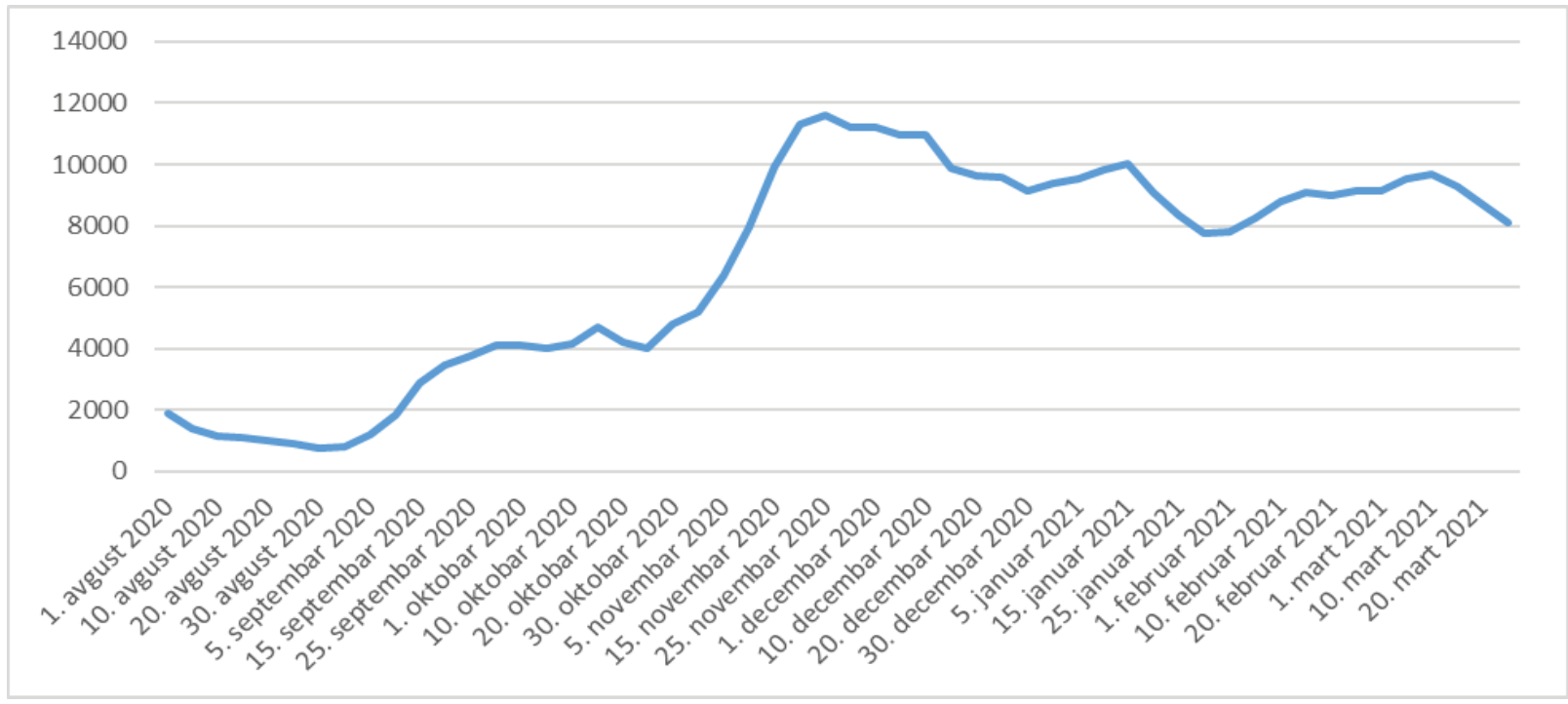

Grafikon 1 - Trend broja obolelih od SARS-COV-2 virusa poslednjih 8 meseci Graph 1 - Trend in the number of patients with SARS-COV-2 virus in the last 8 months Izvor: Autori / Source: Authors

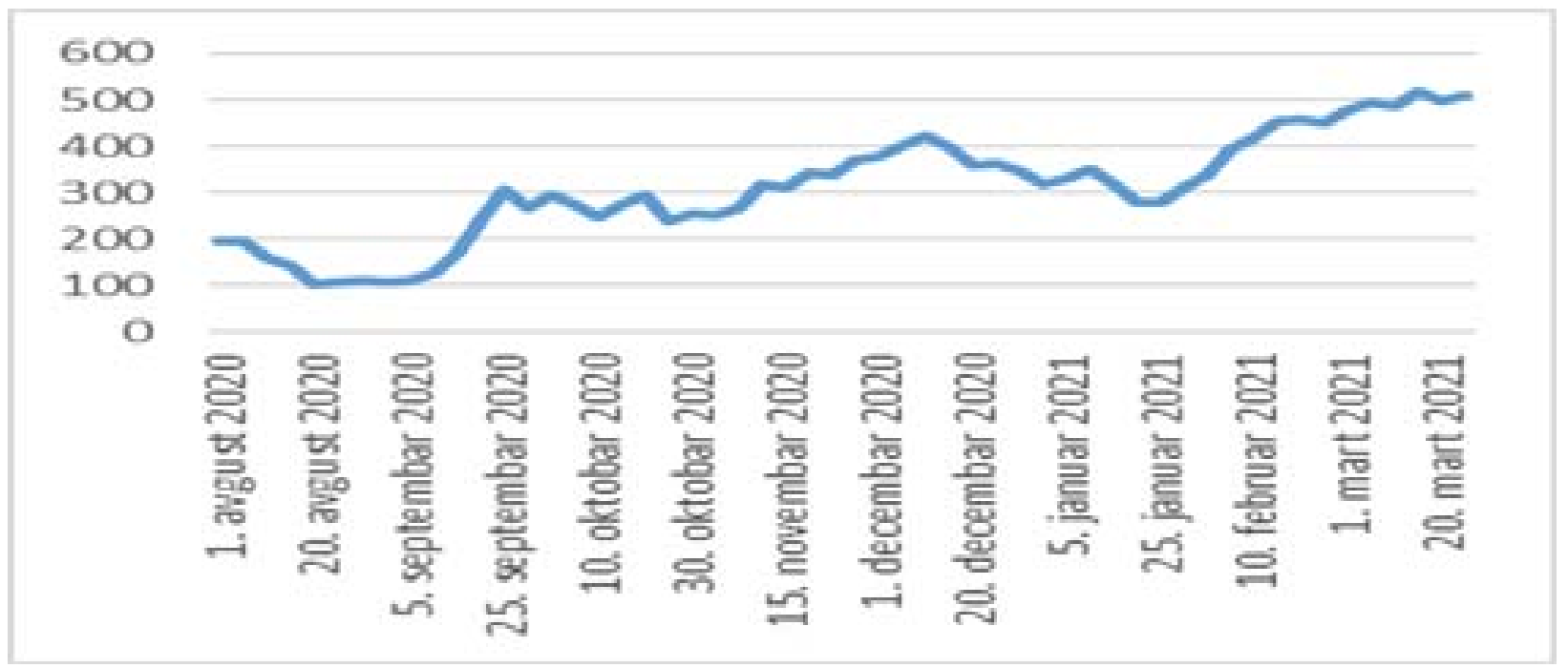

Grafikon 2 - Trend broja hospitalizovanih od SARS-COV-2 virusa poslednjih 8 meseci Graph 2 - Trend in the number of hospitalized SARS-COV-2 virus in the last 8 months Izvor: Autori / Source: Authors

\section{ZAKLJUČAK / CONCLUSION}

Do današnjeg dana COVID-19 je pogodio gotovo sve zemlje i više od 130 miliona ljudi širom sveta. Pored zdravstvene krize, opšte je poznato da je pandemija pokrenula i ozbiljnu ekonomsku krizu, a pretpostavke su da mnoge ekonomije neće oporaviti nivo proizvodnje najranije do 2022. godine.

Posledice koje je pandemija COVID-19 ostavila po zdravlje stanovništva, zdravstveni sistem i ekonomiju ponovo su afirmisale značaj kriznog menadžmenta i njegov odgovor na ovakvu situaciju. Nažalost, praksa je pokazala da se ovom segmentu menadžmenta nije posvetilo dovoljno pažnje. Neade- kvatno reagovanje, nespremnost za pravilan odgovor za suzbijanje i sanaciju pandemije, rezultiraće posledicama dugotrajnog karaktera u svim segmentima društvenog sistema.

Takođe, praksa je ukazala na postojanje jaza između zemalja u odgovoru kriznog menadžmenta na nastale događaje. Pred COVIDOM-19 pokleknuli su i najstabilniji zdravstveni sistemi. U narednom periodu potrebno je akcentirati izradu takvih dugoročnih kriznih planova koji će omogućiti pravovremene i adekvatne odgovore zdravstvenih sistema na slične događaje. Ovi planovi podrazumevaju analizu svih manjkavosti i nedostataka koje su zdravstveni sistemi 
pokazali uz njihovo otklanjanje, oporavak, kao i pripremu i spremnost za odgovore na neke nove događaje koji bi se u budućnosti mogli desiti.

\section{LITERATURA / REFERENCES}

[1] Adižes, I., (2009), Kako upravljati u vrijeme krize: (i kako je, prije svega, izbjeći), Asee d.o.o., Zagreb.

[2] Global Health Security Index, (2019), www.ghsindex.org

[3] Dobričanin, V., Đokić, N., Dobričanin, S., (2018), The role of health system in emergency response planing, Journal of Medical Faculty, University of Kargujevac, Ser J Exp Clin Res 2017; 1-1. DOI:10.2478/sjecr-2018-0011,

[4] Ekonomski i socijalni uticaj COVID-19, Zdravstveni sistemi, Redovni ekonomski izveštaj br. 17, 2020, www.pubdocs.worldbank.org/

[5] Inter-Agency Standing Committee (IASC). Health Cluster Guide - A practical guide for countrie-level implementation of the Health Cluster. World Health Organization. 2009. https://www.who.int/emergencies/diseases/no vel-coronavirus-2019

[6] Ivanović, V., (2014), Pojam krize: konceptualni i metodologijski aspekti, Međunarodne studije, Vol. 14 No. 2, str. 10-28, www.hrcak.srce.hr

[7] Keković, Z., (2020), Upravljanje krizom COVID19 - izazov za donosioce odluka, Kriza COVID-19: od menadžerske teorije do prakse, Institut za standardizaciju Srbije, Centar za analizu rizika i upravljanje krizama, Beograd, str. 45

[8] Kešetović, Ž., Toth, I., (2012), Problemi kriznog menadžmenta, Veleučilište Velika Gorica, Velika Gorica, str. 53.

[9] Marković, S., Milošević, O., Ditrih, S., (2020), Institucionalni odgovor na vanredne situacije u Republici Srbiji, Ecologica, 27(98), str. 325-332.

[10] Milašinović, S., Kešetović, Ž., (2009), Krizni menadžment, Kriminalističko-policijska akademija, Beograd, str. 223.

[11] Milašinović, S., Kešetović, Ž., Nadić, D., (2010), Moć i nemoć kriznog menadžmenta u suočavanju sa modernim krizama, Megatrend revija, 7(2), str. 275-292.

[12] Radanov, P., (2020), Informisanost stanovnika grada Pančeva o korona virusu-izazivaču teškog akutnog respiratornog sindroma i merama zdravstvene zaštite, Ecologica, 27(98), str. 288-293.

[13] Ristanović, (2020), Zdravstveni aspekti KOVIDA-19 u ogledalu realnog vremena, Kriza COVID-19: od menadžerske teorije do prakse, Institut za standardizaciju Srbije, Centar za analizu rizika i upravljanje krizama, Beograd, str. 35

[14] Senić, V., Senić, R., (2015), Komunikacija u uslovima krize, Marketing 46(3), str.155-165.

[15] http://www.oecd.org/coronavirus/policyresponses/the-territorial-impact-of-covid-19managing-the-crisis-across-levels-ofgovernment-d3e314e1. 